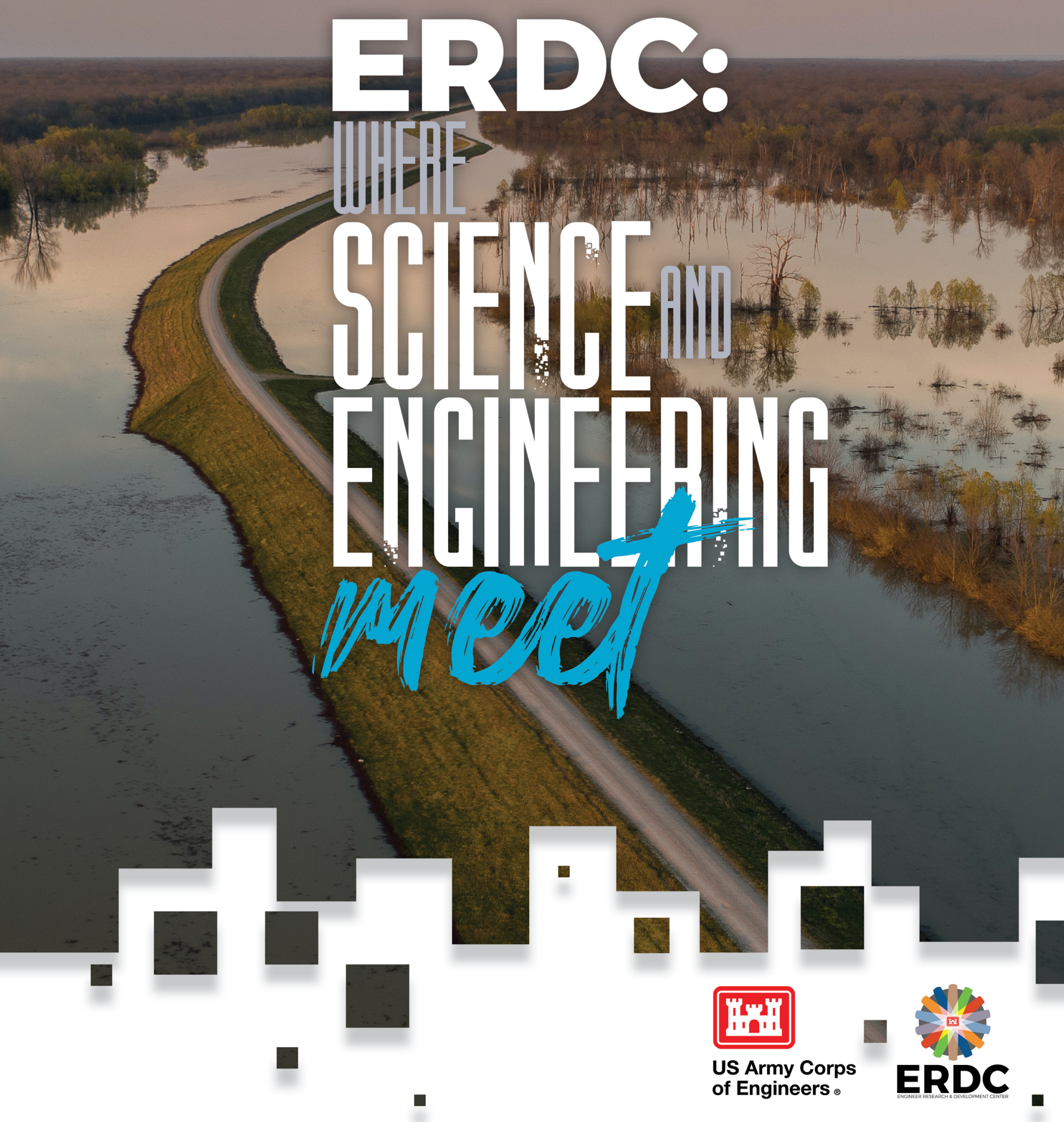




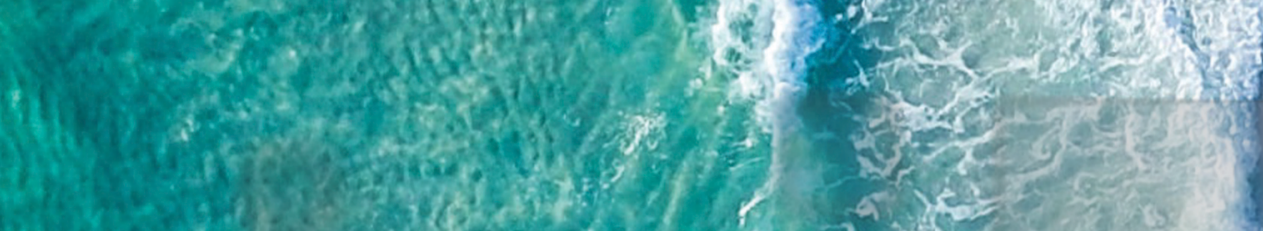

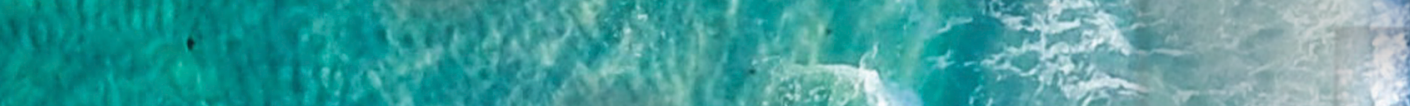

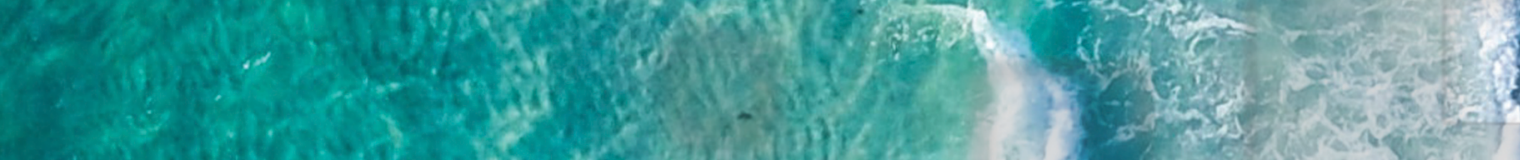
(2) 3

. (i) Howites

nes g ghis

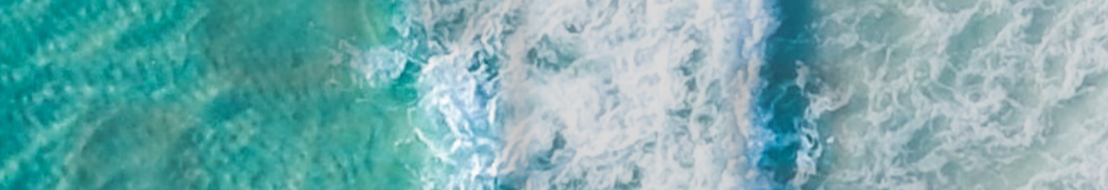

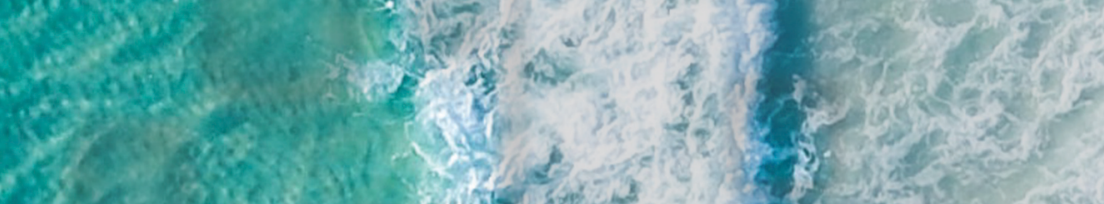

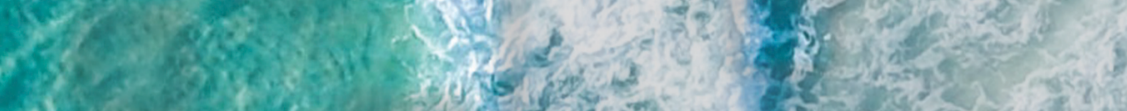

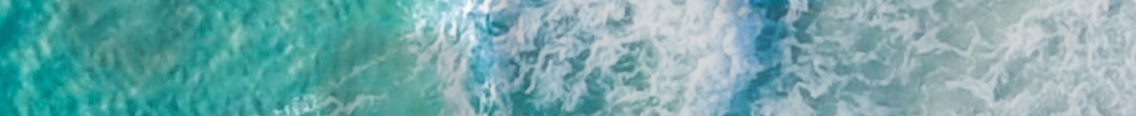
,

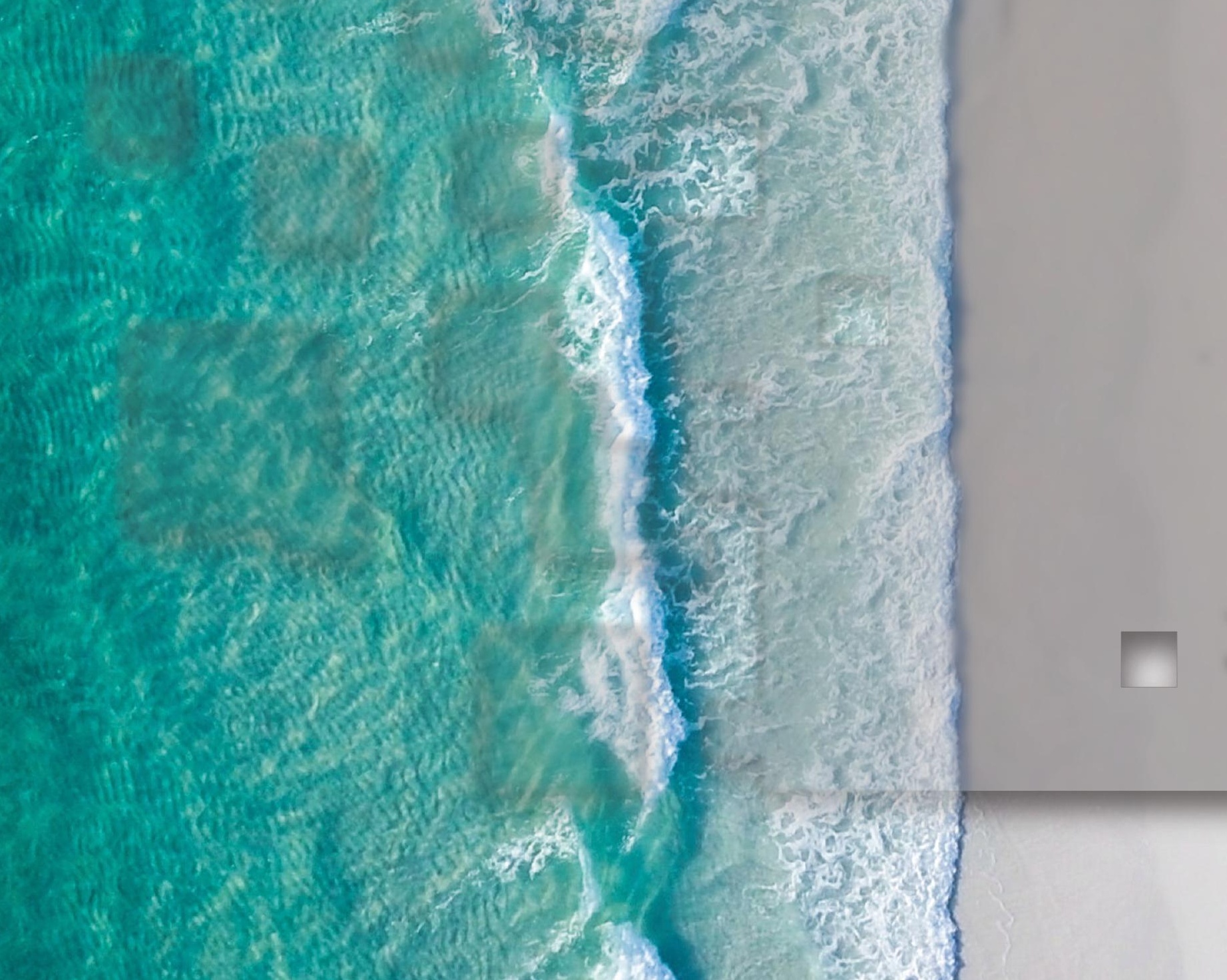




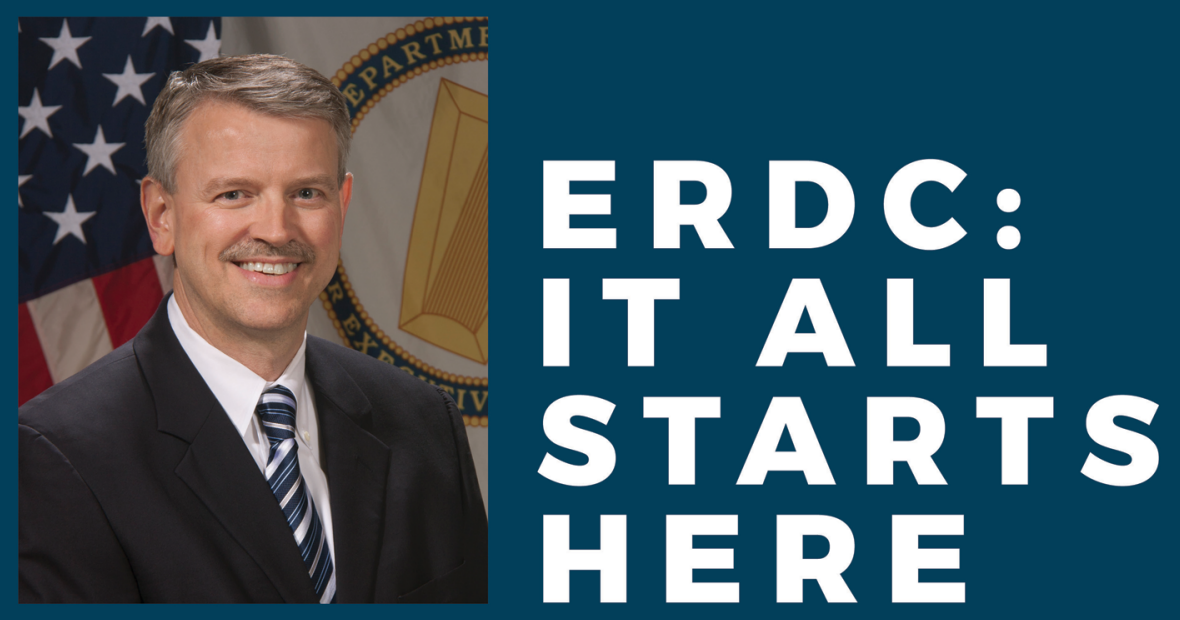

Throughout our history, which began as the Waterways Experiment Station in 1929, we have confronted some of our nation's greatest scientific and engineering challenges.

As the U.S. Army Engineer Research and Development Center, we stand at the leading edge of $\mathrm{R} \& \mathrm{D}$, discovering, developing and delivering solutions that make the world safer and better every day. This is not only our mission, but also our calling.

In leveraging world-class facilities and capabilities, combined with our people and their expertise, ERDC is shaping the engineering and science solutions of today and building a foundation of excellence to meet the demands of tomorrow.

Recently, USACE unveiled its Research and Development Strategy, outlining 10 areas where vital R\&D solutions are needed. "This Strategy takes a new programmatic approach to $R \& D$, elevating R\&D's role within USACE as we increase our value to the nation," Lt. Gen. Scott Spellmon, 55th Chief of Engineers and USACE Commanding General, said in the strategy's release.

This comprehensive strategy serves as a reminder of how valuable our work is, the difference it can make, and the positive impact we can have on the lives of people around the world.

We are an organization that thrives when confronted with challenges, and never before in our history has our nation and world faced so many challenges at once.

While I am proud to serve as ERDC's director, my greatest pride comes from working with and alongside so many great people at a time when great solutions are needed. Our people are the key to our success today and tomorrow and are the true Power of ERDC.

Today, we are entering a bold, new era for $\mathrm{R} \& \mathrm{D}$.

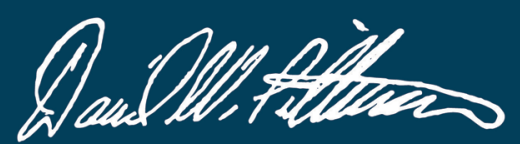

DAVID W. PITTMAN, PE, PhD, SES

Chief Scientist and Director of R\&D, U.S. Army Corps of Engineers

Director, U.S. Army Engineer Research and Development Center 


\section{ERDC STRATEGY}

ERDC seeks to be the 'go-to' organization for the nation and our Armed Forces for solving big, complex problems in our mission space; for putting solutions into practice; and for producing results, outcomes and products that become the world standard.

We succeed because of our premier research facilities and capabilities; our extensive experience and history in finding solutions; our partnerships across the Department of Defense, industry and academia; and primarily because of our people, who are leading experts in their fields.

\section{ERDC RESEARCH AND DEVELOPMENT AREAS (RDAS) INCLUDE:}

- Military Engineering

- Civil Works

- Installation and Operational Environments

- Geospatial Research and Engineering

- Engineered Resilient Systems
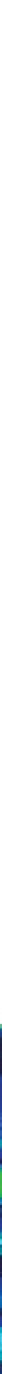


\section{ERDC CORE COMPETENCIES}

ERDC's Core Competencies are those that USACE, Army and DOD recognize as ERDC leadership roles for the department. They are technology enablers not commonly found in the private sector or academia that represent a critical, unique need for the Army and DOD.

\section{BLAST AND WEAPONS EFFECTS ON STRUCTURES AND GEO-MATERIALS:}

Enables understanding and prediction of weapons effects on surface/underground structures, and shapes solutions that counter and neutralize our adversary's energetic weapons.

\section{BATTLESPACE TERRAIN MAPPING AND CHARACTERIZATION: Focuses on} geospatial understanding of the operational environment, development of innovative mapping technologies, data management and analytics, and spatial and temporal applications that enable mission command.

COLD REGIONS SCIENCE AND ENGINEERING: Understanding/managing the challenges of operations in cold regions key to achieving operational capabilities of enhanced mission command, mobility and maneuver, and navigation/flood risk management in Arctic regions and mid- to high-latitudes and high elevations.

CIVIL AND MILITARY ENGINEERING: Technology leadership necessary for force protection, force projection and sustainment, and civil works missions (navigation, flood and coastal risk management, environmental sustainability, and hydropower and water supply).

COMPUTATIONAL PROTOTYPING FOR MILITARY PLATFORMS: Advanced engineering tools and techniques, and high-performance computing, to amplify/ accelerate design operations early in the acquisition process.

COASTAL, RIVER AND ENVIRONMENTAL ENGINEERING: ERDC has a long history of leading the engineering profession in coastal, river and environmental engineering and related sciences.

MILITARY INSTALLATIONS AND INFRASTRUCTURE: Much of what is known today was developed in ERDC's 93-year history. Military Installations and Infrastructure enables military construction, installation support and Warfighter operations support overseas and in the battlespace, ensuring facilities, infrastructure and installation services are resilient, ready and efficient.
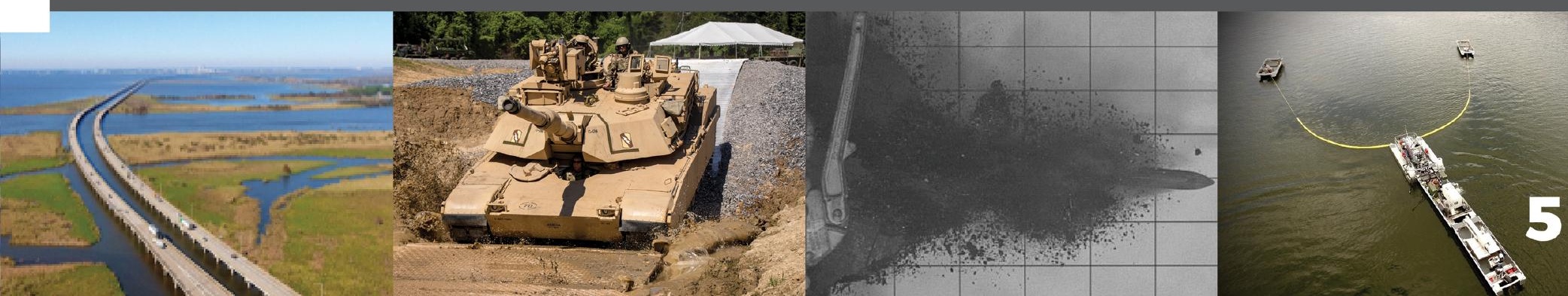


\section{USACE R\&D STRATEGY: \\ A BOLD NEW ERA}

During a visit to the U.S. Army Engineer Research and Development Center in January 2021, Lt. Gen. Scott Spellmon issued a challenge that we must elevate and open a bold, new era for R\&D within USACE.

In adopting that challenge from our leader, USACE and ERDC officials developed the "USACE Research and Development Strategy" and named 10 priorities to help guide our world-class R\&D capabilities.

In adopting these "Top Ten R\&D Priorities," we seek to apply our talents, our facilities and most of all, the top-notch expertise of our people - the Power of ERDC - to find innovative solutions to some of the toughest engineering challenges faced by our generation, or any other.

For decades, our R\&D efforts have been focused on civil works, installations and operational environments, supporting our nation's Warfighter and helping others. While those key areas remain, this new alignment allows us to be more targeted in our approach.

From taking on the challenge of mitigating the impact of climate change, to discovering vital solutions to both protecting and defending the Arctic, USACE and ERDC have the experience and passion to thrive in this time of heightened research and development.

Investment in strategic $R \& D$ is a force multiplier. Successful outcomes in each priority area will be measured in two ways: how well they support the advancement of national priorities and how they enable USACE to deliver its mission more efficiently and effectively - faster, cheaper, stronger, safer and smarter.

\section{SCAN USING YOUR SMART PHONE DEVICE}

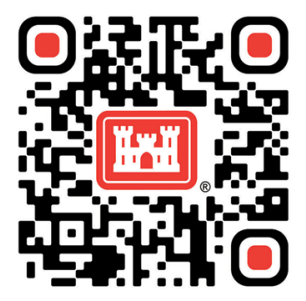

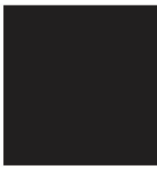


$\approx$ MITIGATE AND ADAPT TO CLIMATE CHANGE

F⿳⺈⿴囗十大 WIN FUTURE WARS

MODERNIZE OUR NATION'S INFRASTRUCTURE

$0 \%$

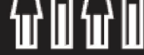

SUPPORT RESILIENT COMMUNITIES

29ie

ENABLE SMART AND RESILIENT INSTALLATIONS

Q

Q Secure RELIABle installation energy

\% REVOLUTIONIZE AND ACCELERATE DECISION-MAKING

Q IMPROVE CYBER AND PHYSICAL SECURITY

$\frac{* 4}{4}$ PROTECT AND DEFEND THE ARCTIC

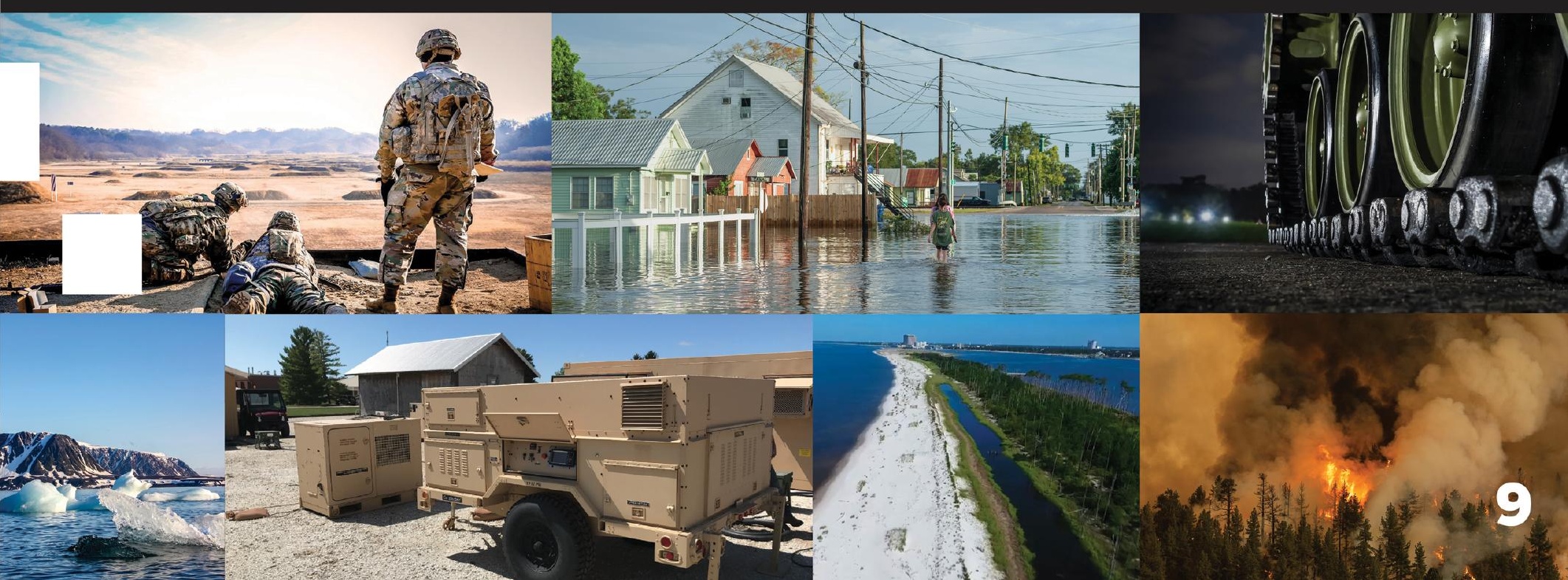




\section{MITIGATE AND ADAPT TO CLIMATE CHANGE}

At no time in our history have the challenges caused by a changing climate been more ominous. However, while these challenges are historic, so are the human capabilities to confront them. USACE and ERDC are researching more resilient and rehewable energy resources, developing better ways to curtail greenhouse gas emissions, and delivering better models to forecast extreme weather, events. in in

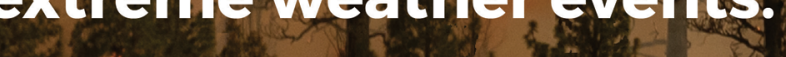




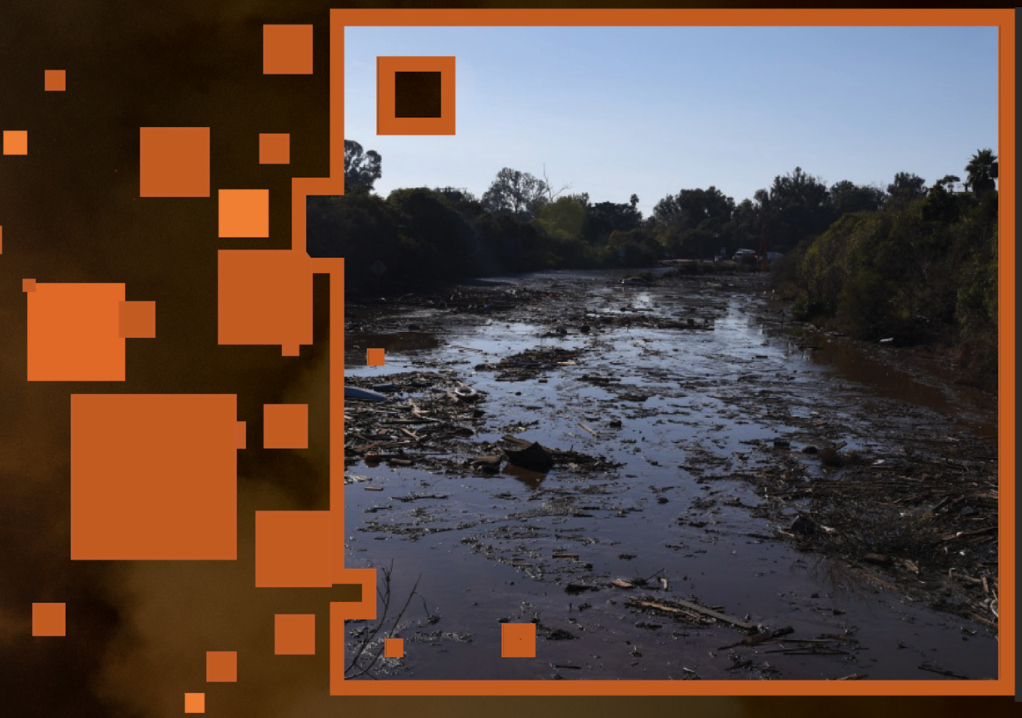

\section{Post-Wildfire Flood Risk Management}

ERDC provides accurate modeling forecasts for post-wildfire flood debris flows, helping emergency management officials better plan evacuations.

\section{8:1 RETURN on pre-hazard mitigation capability investment}

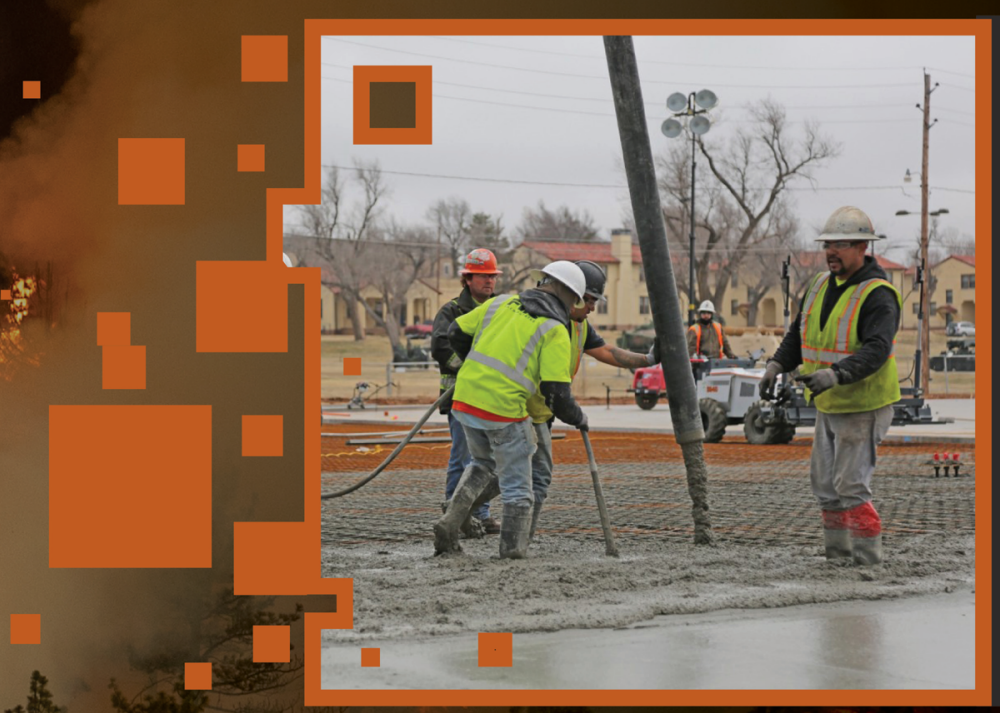

\section{Low Carbon Footprint} Construction Materials ERDC and partners are developing new materials that significantly reduce the carbon footprint, including the ability to permanently sequester carbon.

Near-term reductions in carbon footprint UP TO 30\% over next five years

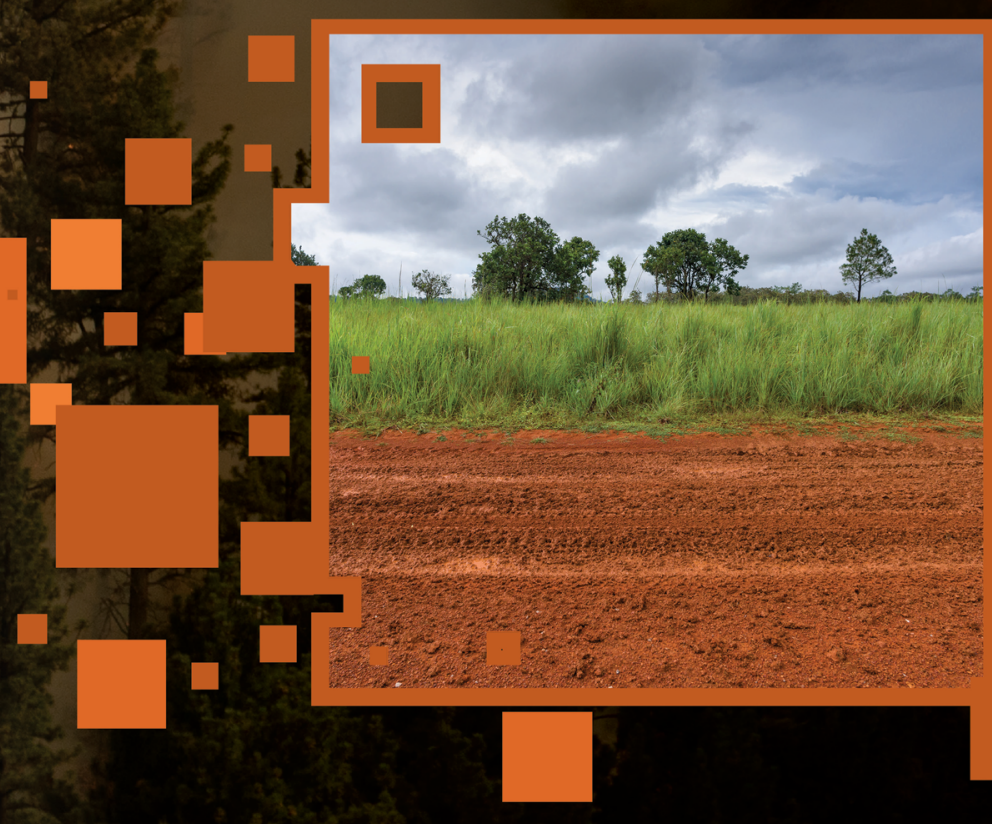

\section{Carbon Sequestration Toolkit for DOD Lands}

ERDC toolkit will enable installation leadership to estimate and maximize carbon sequestration on DOD lands.

\section{Accounts for $50-80 \%$} of DOD greenhouse gas emissions and promotes additional annual carbon storage increases 


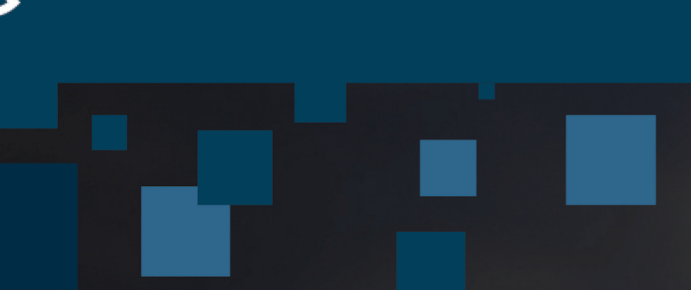

R\&D of new and nimble technologies is vital to ensuring the U.S. military's advantage in' the battlespace, whether that is on land, in the air, at sea or in space. USACE, fueled/by ERDC research, provides the innovation, creativity and entreprenęurship that prepares the military for the conflicts of today and tomorrow. 


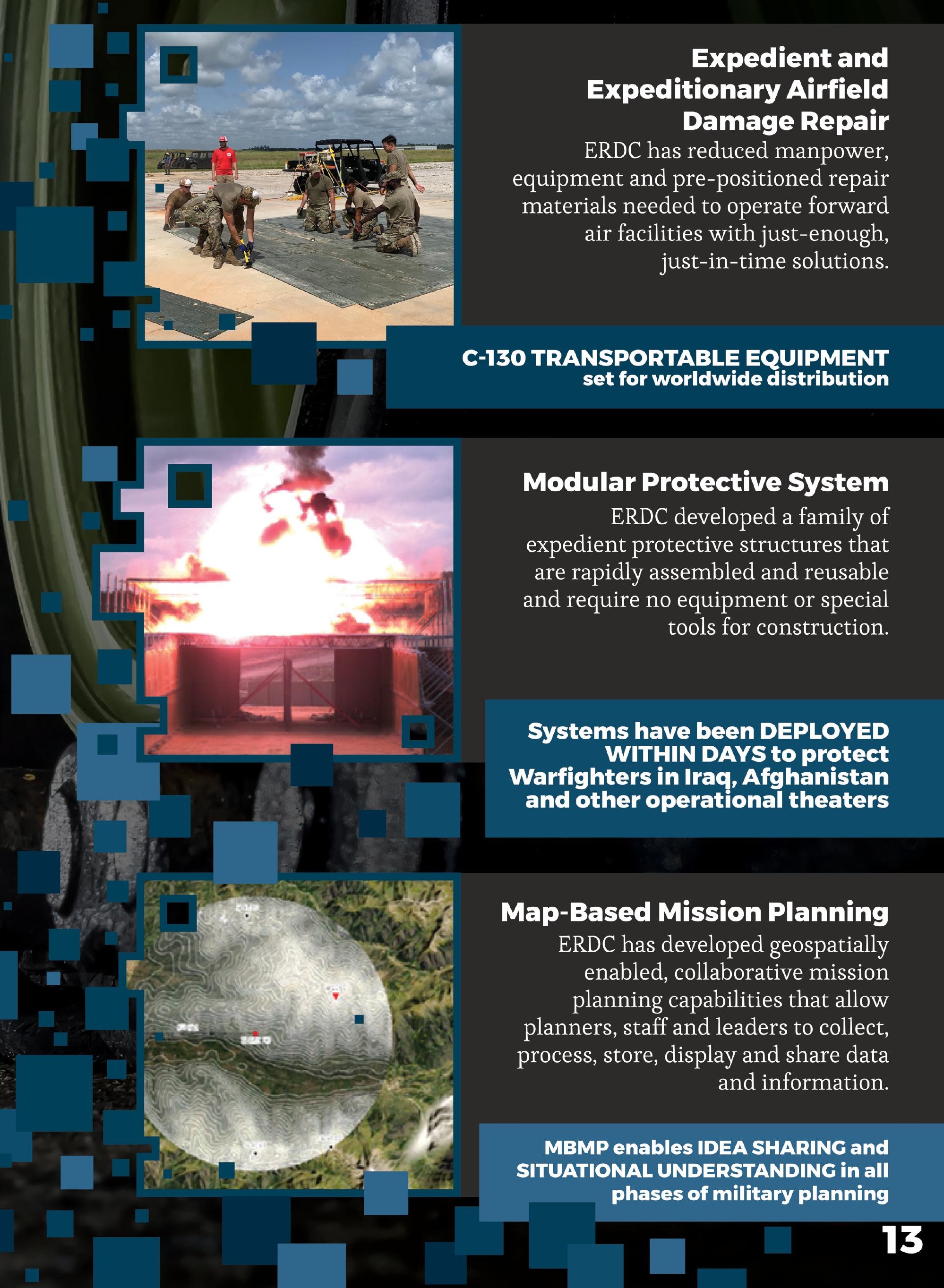




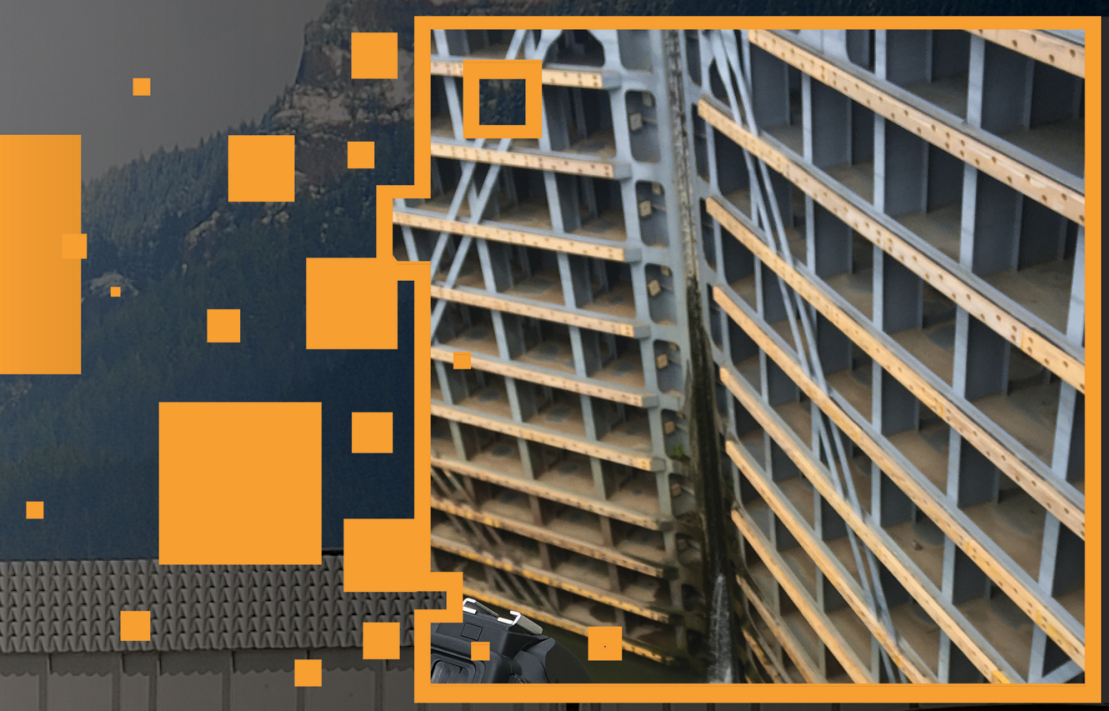

\section{Fiber-Reinforced Polymers}

ERDC developed a process to use FiberReinforced Polymers to repair fatigueinduced cracks in hydraulic steel structures, increasing service life and reducing repair time at significantly lower costs.

\section{$\$ 2$ (annually) operation and maintenance savings on one typical navigation project}

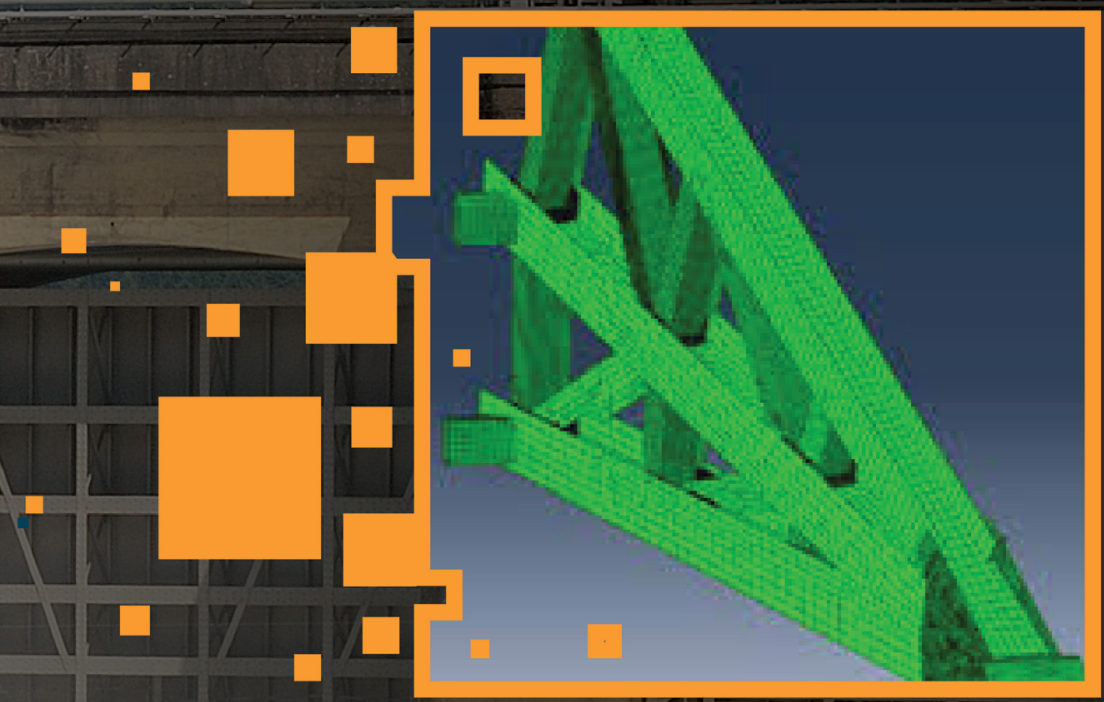

\section{SMART Gate}

ERDC developed a platform for datadriven decision making to support optimization to operate and invest in infrastructure assets.

\section{Avoid unscheduled lock outages, which cost local economies approx. \$3M PER DAY}

\section{4a)}

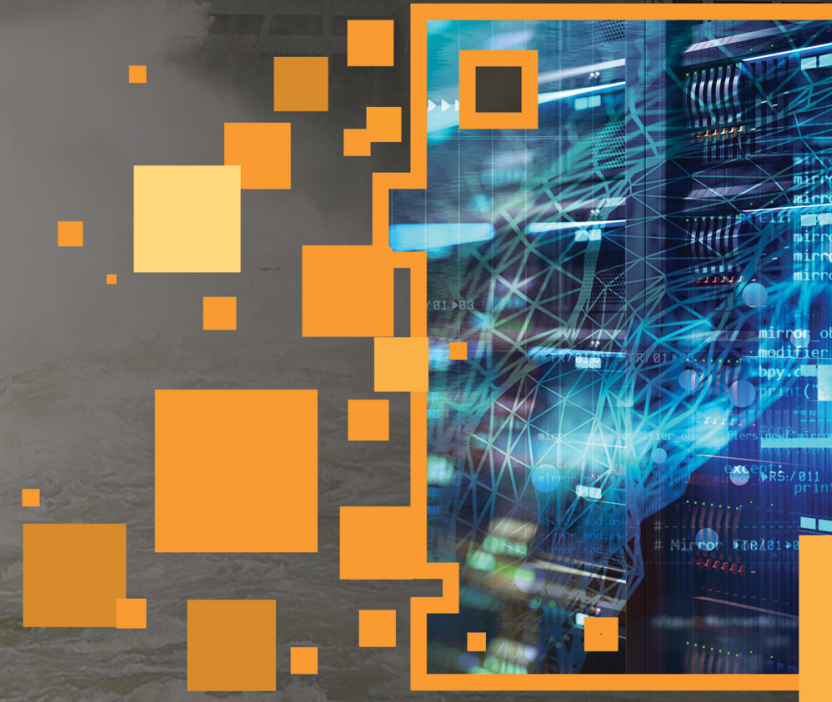

\section{Digital Twins}

ERDC-developed digital twins of USACE infrastructure will streamline data processing and analysis and provide a centralized platform for modeled scenario conditions to inform decision making.

REDUCED TIME to achieve outcomes by $/ 50 / 0$ and REDUCED REACTIVEMAINTENANCE by $/ 1,000$ 


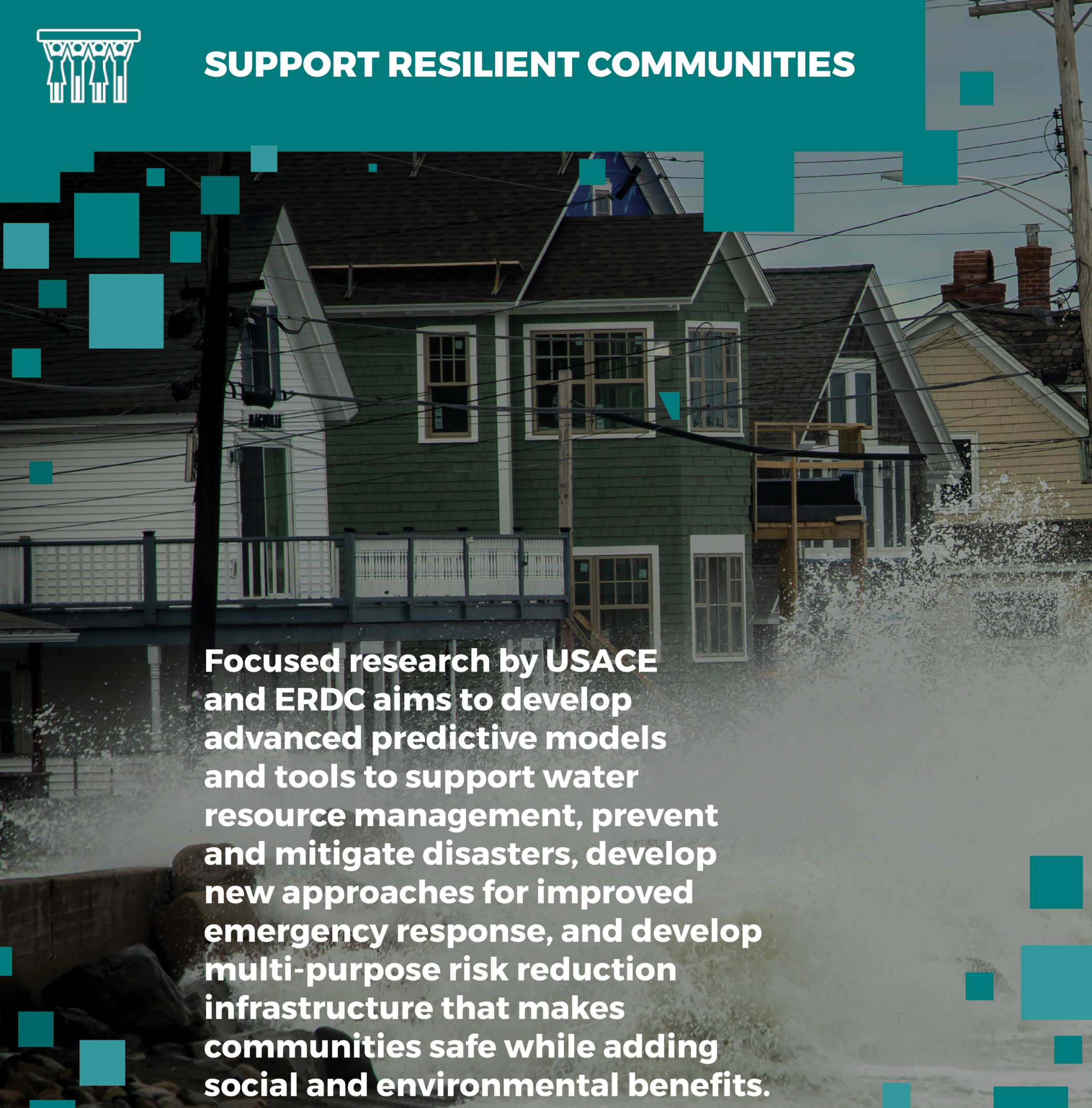





\section{aNABLE SMART AND \\ RESILIENT INSTALLATIONS}

USACE and ERDC R\&D are developing technologies and analytical capabilities to nurture smart installations that save money and energy and are more resilient to risks and hazards. The U.S. Army's greatest strength is its people, and the installations where they work and, in many cases, live must keep pace with civilian infrastructure and support a modernized formation. 



\section{Qg ENSURE ENVIRONMENTAL SUSTAINABILITY AND RESILIENCE}

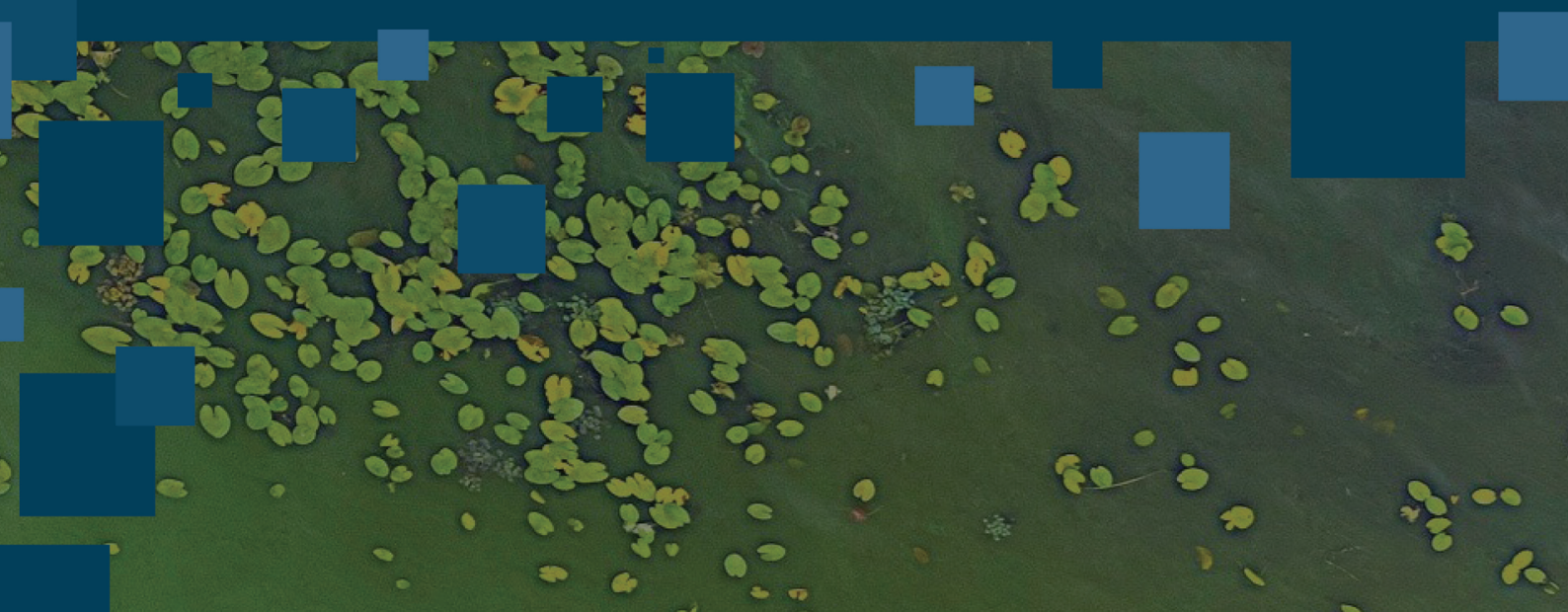

In addition to leading ecosystem restoration activities throughout the country, USACE and ERDC are developing nature-based solutions and programs, such as the USACE Engineering With Nature initiative, to improve and sustain the healith and resilience of écosystems. 


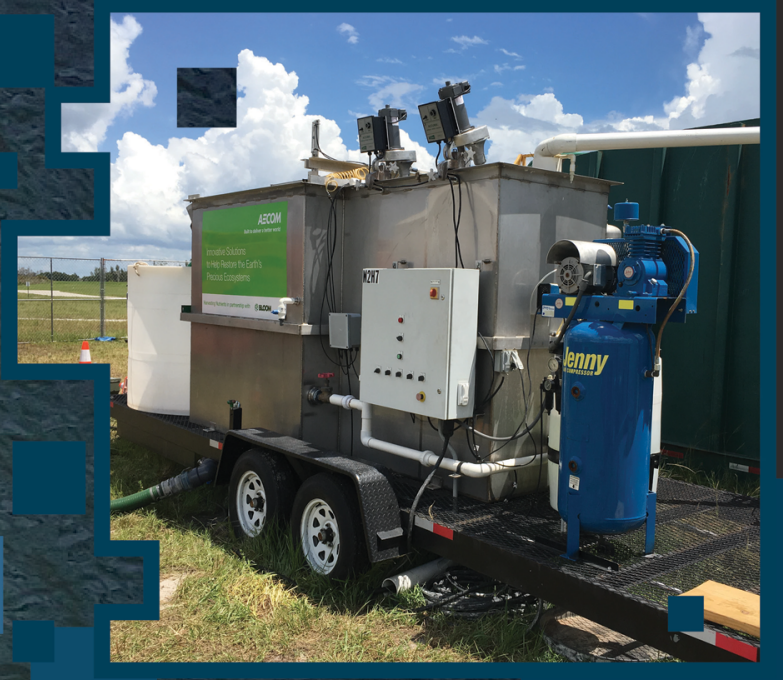

HABITATS

The Harmful Algal Bloom Interception, Treatment and Transformation System provides a scalable capability to remove algae and nutrients from large bodies of water and enable efficient management of the resulting biomass.

\section{Pilots collected 4 G GALLONS of algae slurry and created TOOK GALLONS of clear water}

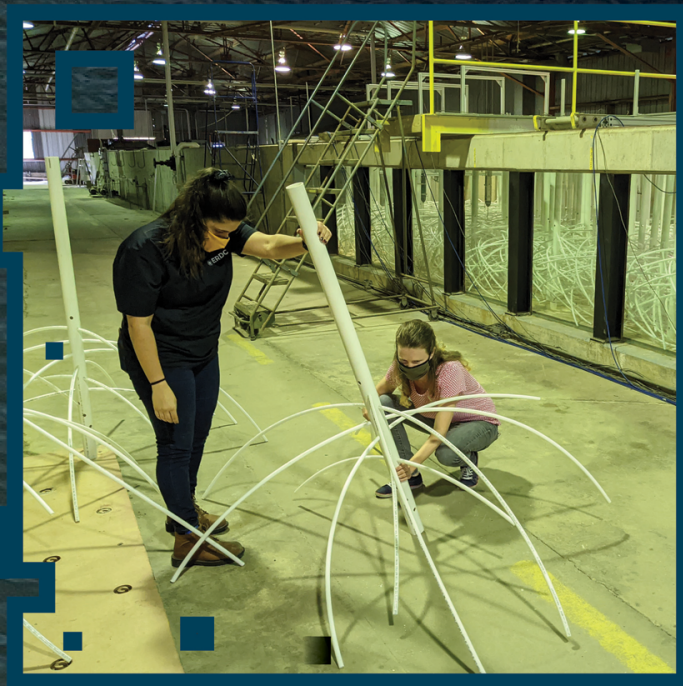

\section{Mangrove Forest Models}

ERDC and U.S. Naval Academy partners built large-scale physical models to provide insight on wave reduction attributed to mangrove forests, enabling greater use of these natural systems for coastal resilience.

Reduces flood damages by $860: 3$

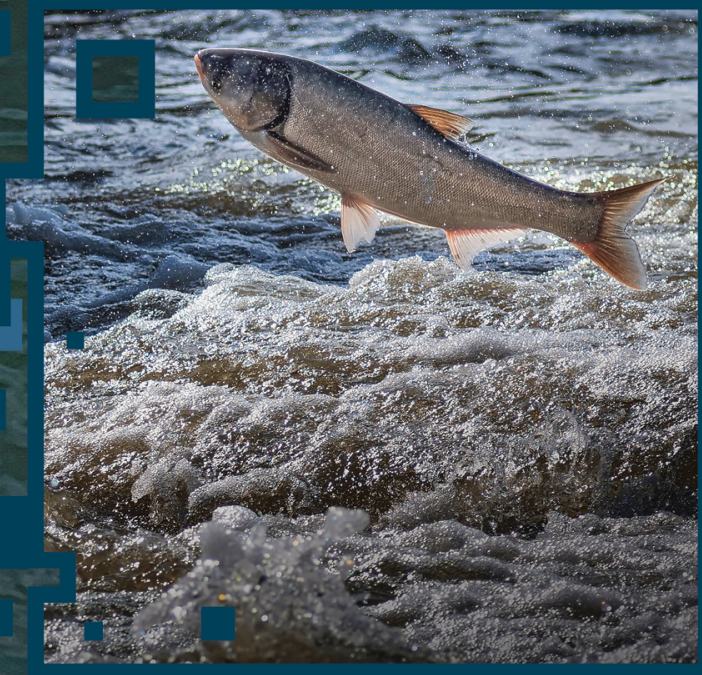

\section{Confronting Invasive Carp}

ERDC research uses swim tunnels and flumes to challenge live invasive carp with various frequencies and duration, providing critical information for electric barrier system protocols.

Preserves healthy SH: BMEAR Great Lakes fisheries 


\section{Q) \\ SECURE RELIABLE INSTALLATION ENERGY}

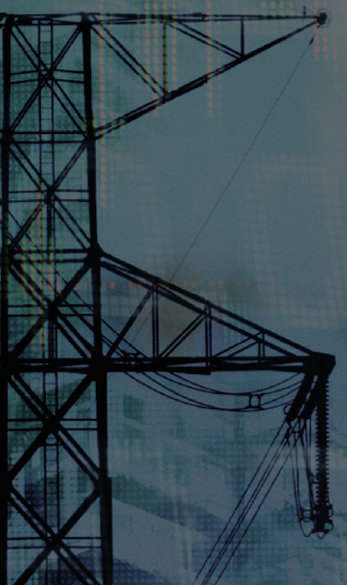

USACE and ERDC R\&D is focused on providing reliable energy systems for our military installations. Development of this innovative technology not only supports the DOD but could have commercial applications.
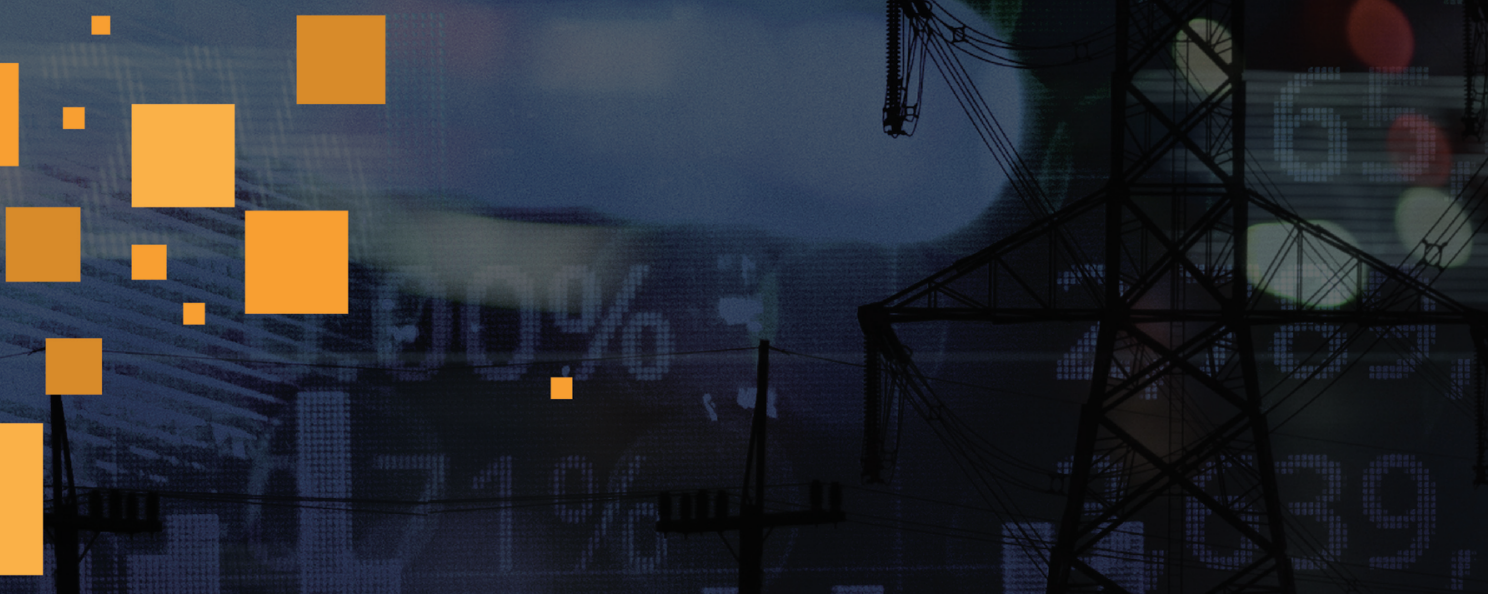


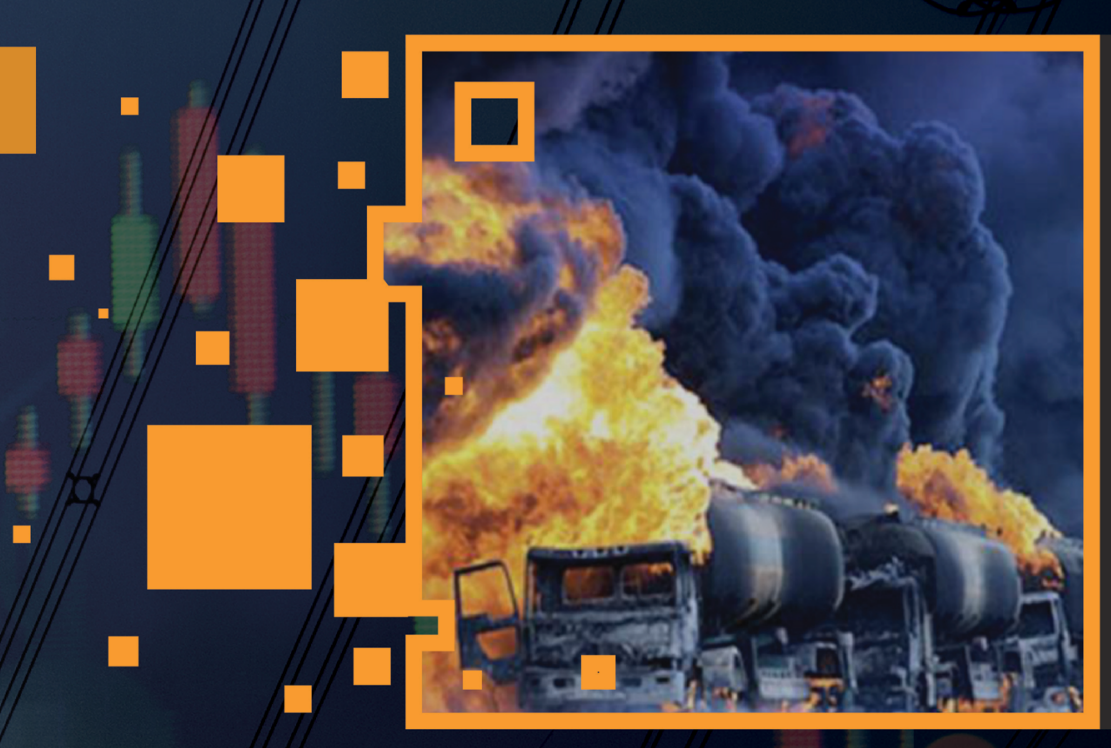

\section{Tactical Microgrids, Mobile Nuclear Power Plants}

Tactical microgrids can support additive manufacturing, hospital power, electric vehicle charging, onsite fuel production, power beaming, electrified rail, missile and air defense, laser defense and more.

MNPPS can provide power for MONTHS TO YEARS on a single fuel load

\section{Fuel Cell Technology}

ERDC is expanding and enhancing fuel cell technology, giving continuous reliable power to mission-critical facilities.

REDUCE DEPENDENCE on utility scale power and fossil fuels and reduce electrical costs
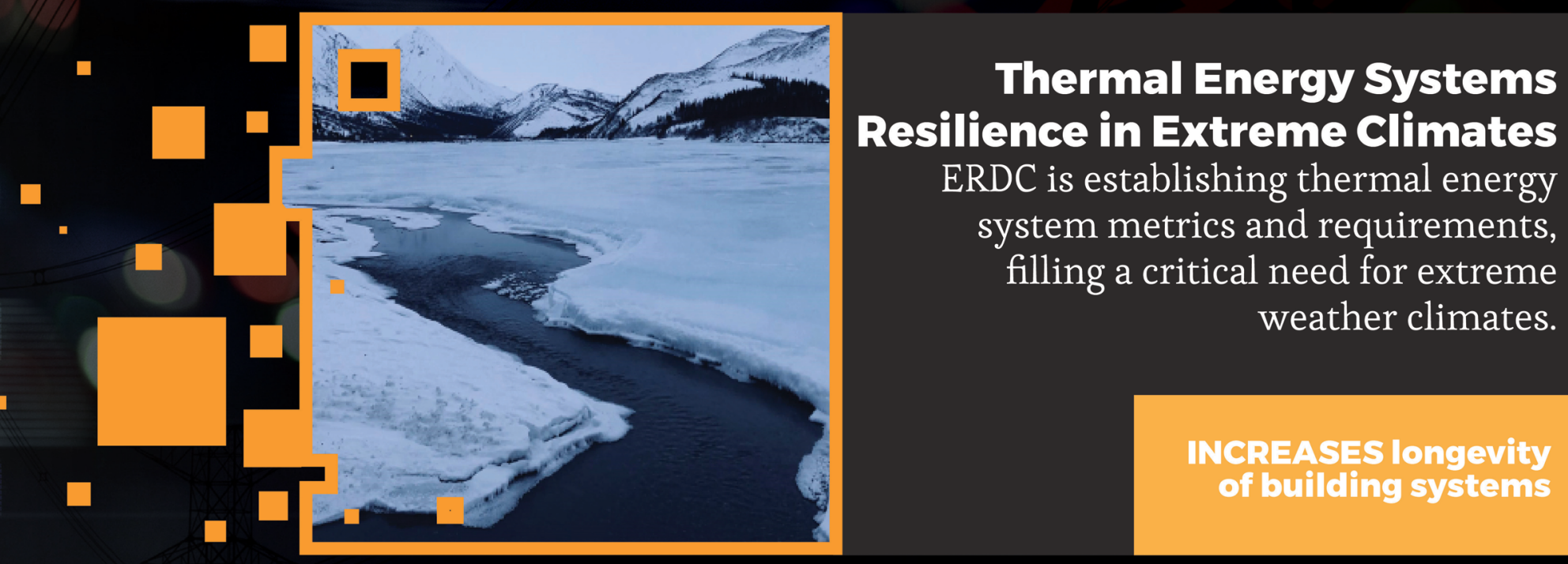

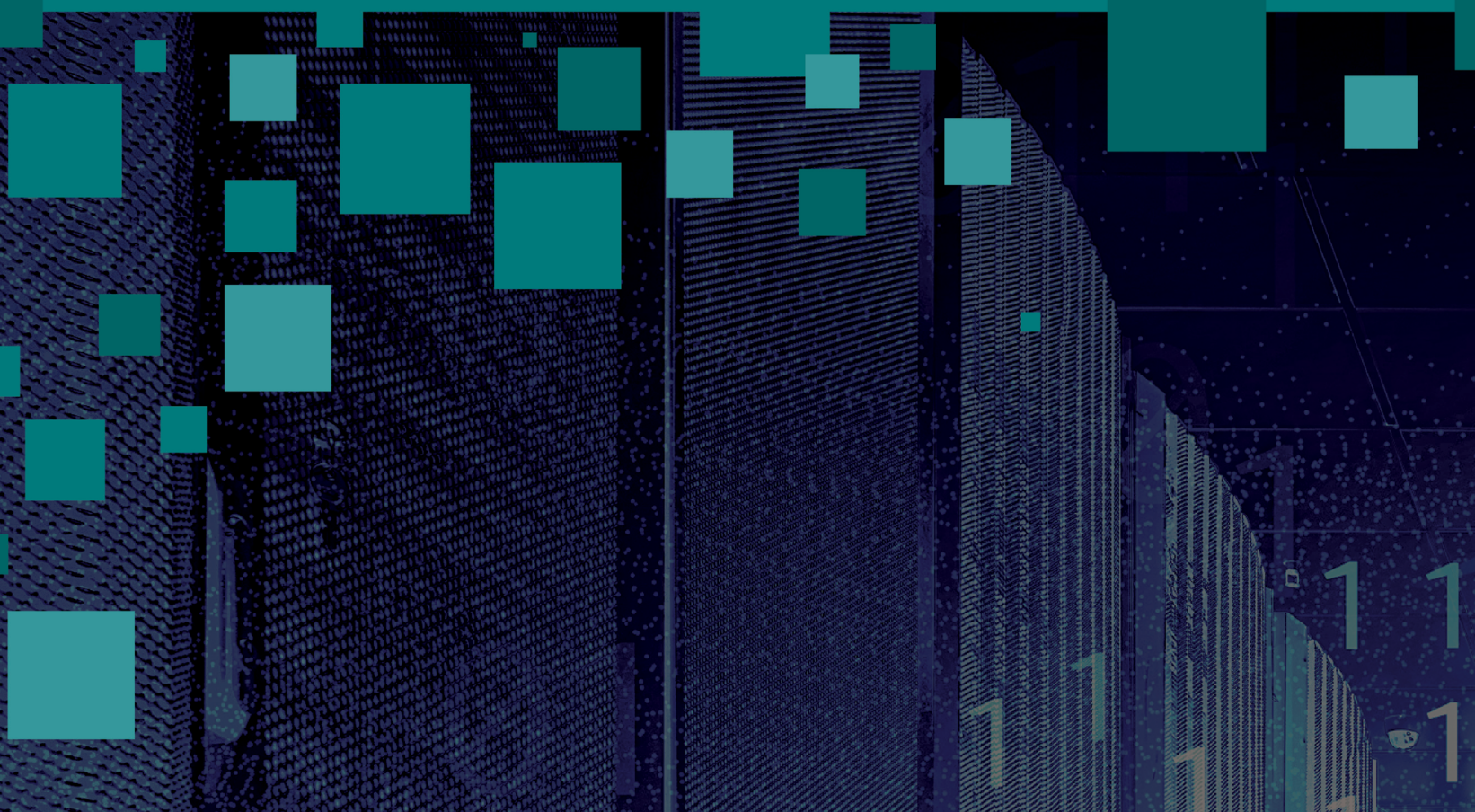

USACE andERDChaU Elecornized the value of machine leating artificial intengence, compurersimutions, autonomy and rotortes and how they revolutionize operatens. 0 reach thits oblect e =RDC is seeving tools that canreduge costs. su eamline operations, anc Inprove decision making through automation and data analysis.

(8)<smiles>[H]</smiles>
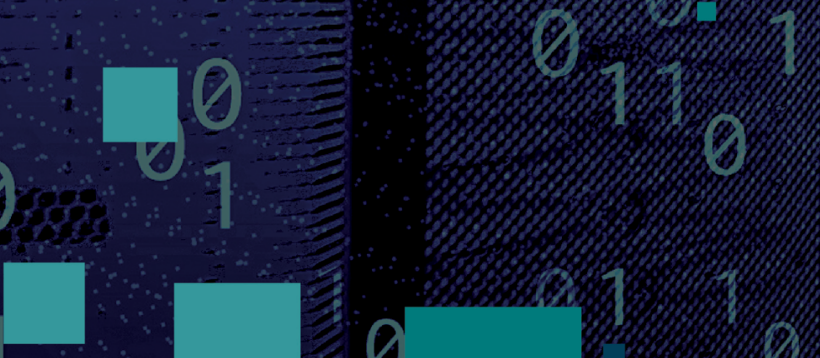

(8) (1) 
The DamBot provides a safer method for inspecting closure gates and other dam components, while giving a more thorough view of the facility's structural health.

\section{REDUCES RISK to inspection personnel and provides RAPID, HIGH-RESOLUTION and repeatable inspections}

\section{Data Analytics for Faster, Effective Solutions}

ERDC is incorporating accurate and faster data analytics to support more efficient dredge and hydropower operations, as well as to predict completion times for ongoing military construction projects to within 85 percent accuracy.

\section{$10 \%$ REDUCTION in overall dredging operation costs}

\section{Engineered Resilient Systems}

ERS combines advanced engineering tools and techniques with unmatched high-performance computing to significantly amplify design options during early stages of the acquisition process. acquisition community 
A IMPROVE CYBER AND

Through innovations in risk detection and reduction, and by leveraging its expertise in support of the Warfighter, USACE and ERDC are conducting R\&D to keep our nation's infrastructure and military safe. Aided by ERDC research, USACE is developing methods to identify cyberattacks and innovative solutions to repel them before damage occurs and - perations are disrupted.
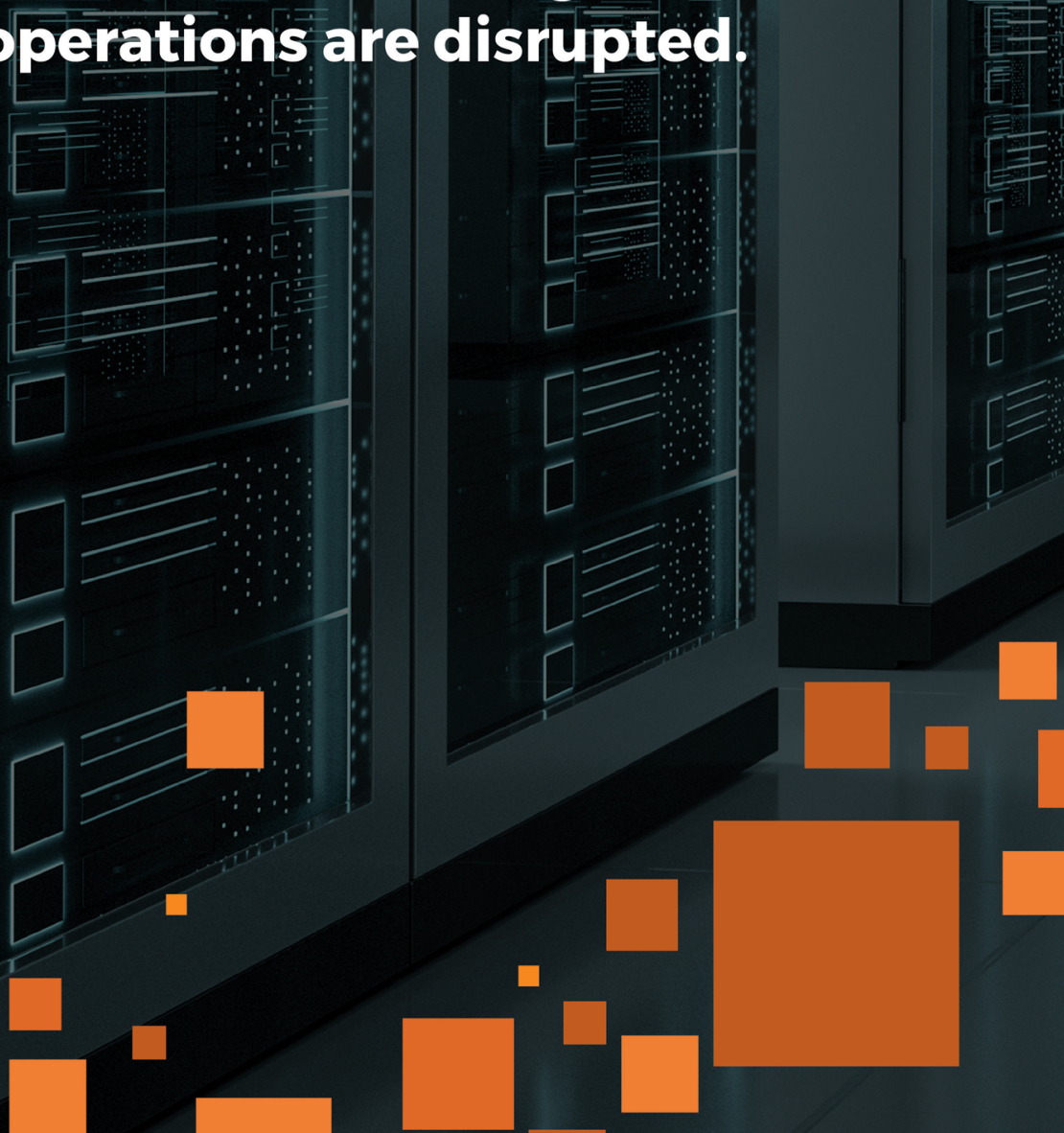


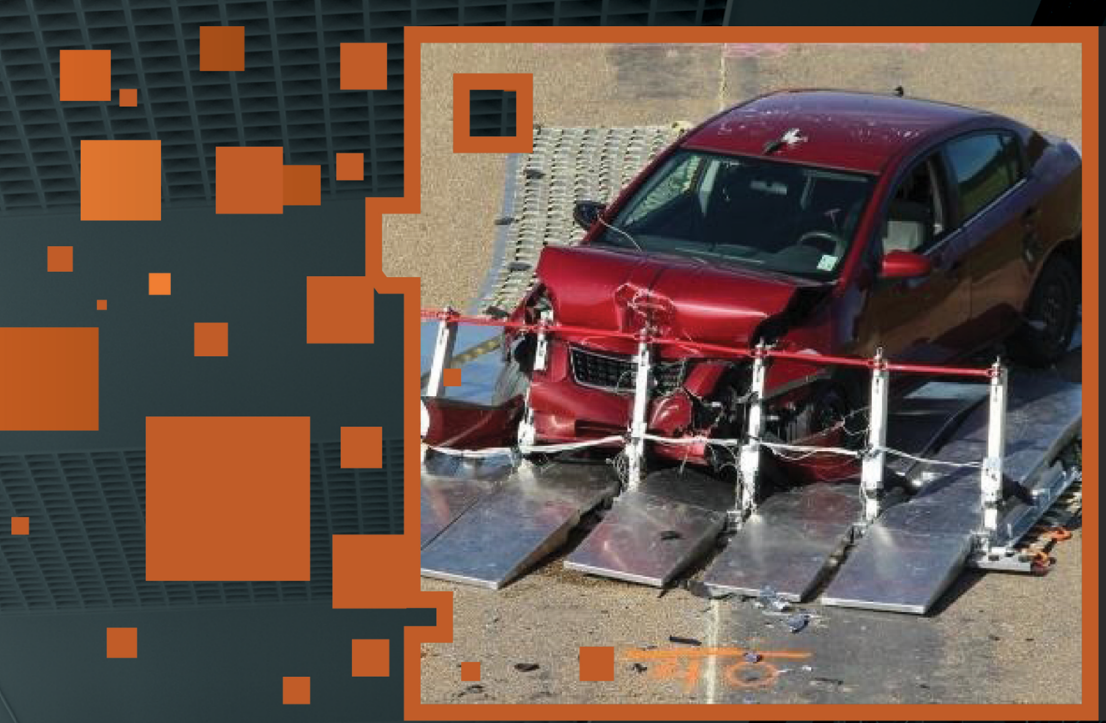

AVERT

A portable barrier designed to stop vehicles in their tracks, the Aggressor Vehicle Entry Readiness Technology will enhance the physical security of military and homeland installations.

\section{Provides an effective vehicle barrier that is PORTABLE, MODULAR and EASY TO ASSEMBLE}

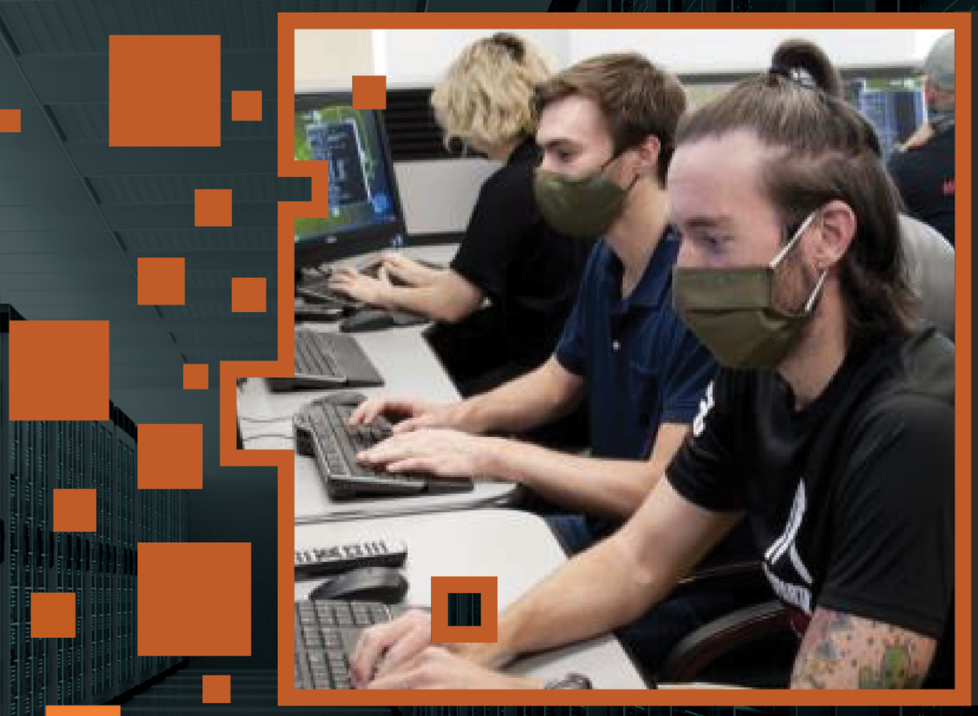

\section{Red Team}

Operating as a Red Team under interim authority from the National Security Agency and U.S. Cyber Command, ERDC's cybersecurity team works to identify potential security holes and where defenses might fail in an attack on a secure network.

IDENTIFIES VULNERABILITIES of information systems

\section{Hardened Alternative Trailer System}

ERDC developed low-cost, versatile and rapidly assembled shelters that are blast and forced-entry resistant, providing superior protection to facilities and personnel around the world.

ROBUST, INEXPENSIVE and EASY to manufacture 


\section{PROTECT AND DEFEND THE ARCTIC}

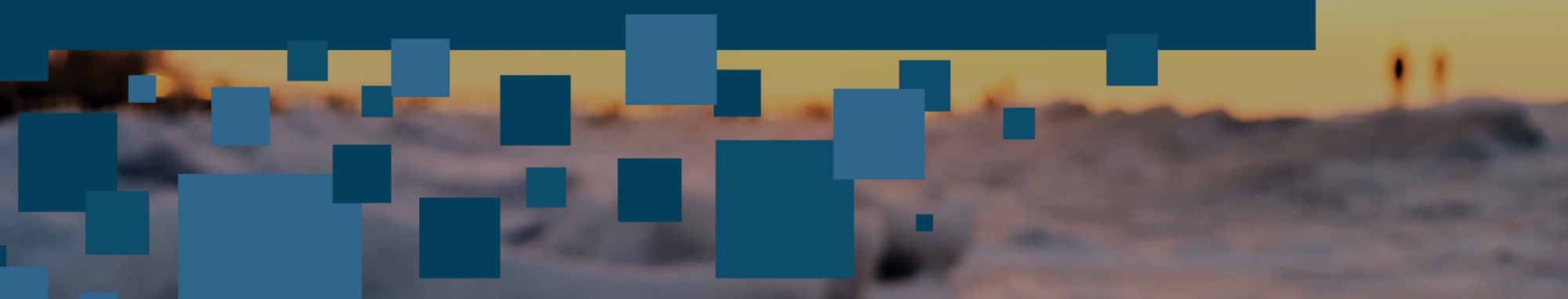

Ongoing R\&D is seeking solutions for the Arctic and other extreme environments to mitigate the impact of climate change to ecosystems and vital infrastructure. Advancements built upon the history of both USACE and ERDC in cold regions research have led to breakthroughs in mapping, modeling, construction and other technologies to ensure operations can be maintained. This work also fits within the DOD's effort to both protect and defend the Arctic. 


\section{ENGINEERING \\ WITH NATURE ${ }^{\circledR}$}

USACE's Engineering With Nature $₫$ initiative is a collaboration of world-class engineers and scientists focused on incorporating nature-based solutions to address infrastructure around the nation and world. These projects produce billions in additional economic, environmental and social benefits, while building more resilient and sustainable solutions and communities. 


\section{Sabine Pass to \\ Galveston Bay CSRM Project}

The USACE Galveston District used innovative

nature-based designs to inform coastal projects and implement a multiple lines of defense strategy that broadened resilience for the Texas energy corridor.

Simulations and harard analysis saved $\$ 300 M$ for the Sabine-to-Galveston Coastal Storm Risk Management Study

\section{Maximizing Long-Term Function of Coastal Islands: Swan Island}

Material from USACE Baltimore District maintenance dredging was used to restore Swan Island and support marsh growth and dune vegetation.

Provides RISK REDUCTION to surrounding islands and supports local ecological systems

\section{Reservoir Sedimentation and Sustainability}

ERDC research provides new and improved methods for stabilizing eroding shorelines, with special emphasis on incorporating in-situ materials and enhancing protection designs with natural components. 
PUBLISH DATE:

FEBRUARY 2022

APPROVED FOR PUBLIC RELEASE DISTRIBUTION UNLIMITED

AUTHORED AND EDITED BY:

ERDC CORPORATE

COMMUNICATIONS OFFICE

DESIGNED BY:

ERDC INFORMATION TECHNOLOGY LABORATORY

FOR MORE INFORMATION CONTACT US AT ERDCINFO@USACE.ARMY.MIL

SCAN USING YOUR SMART PHONE DEVICE

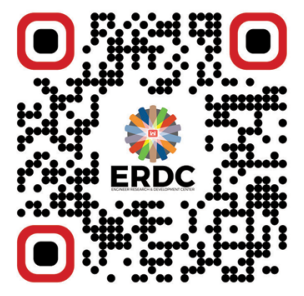

CONNECT WITH US

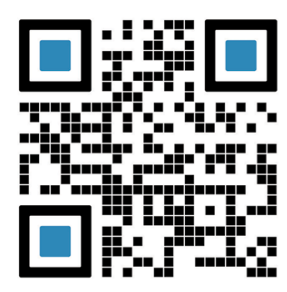

ERDC LIASONS FOR USACE 


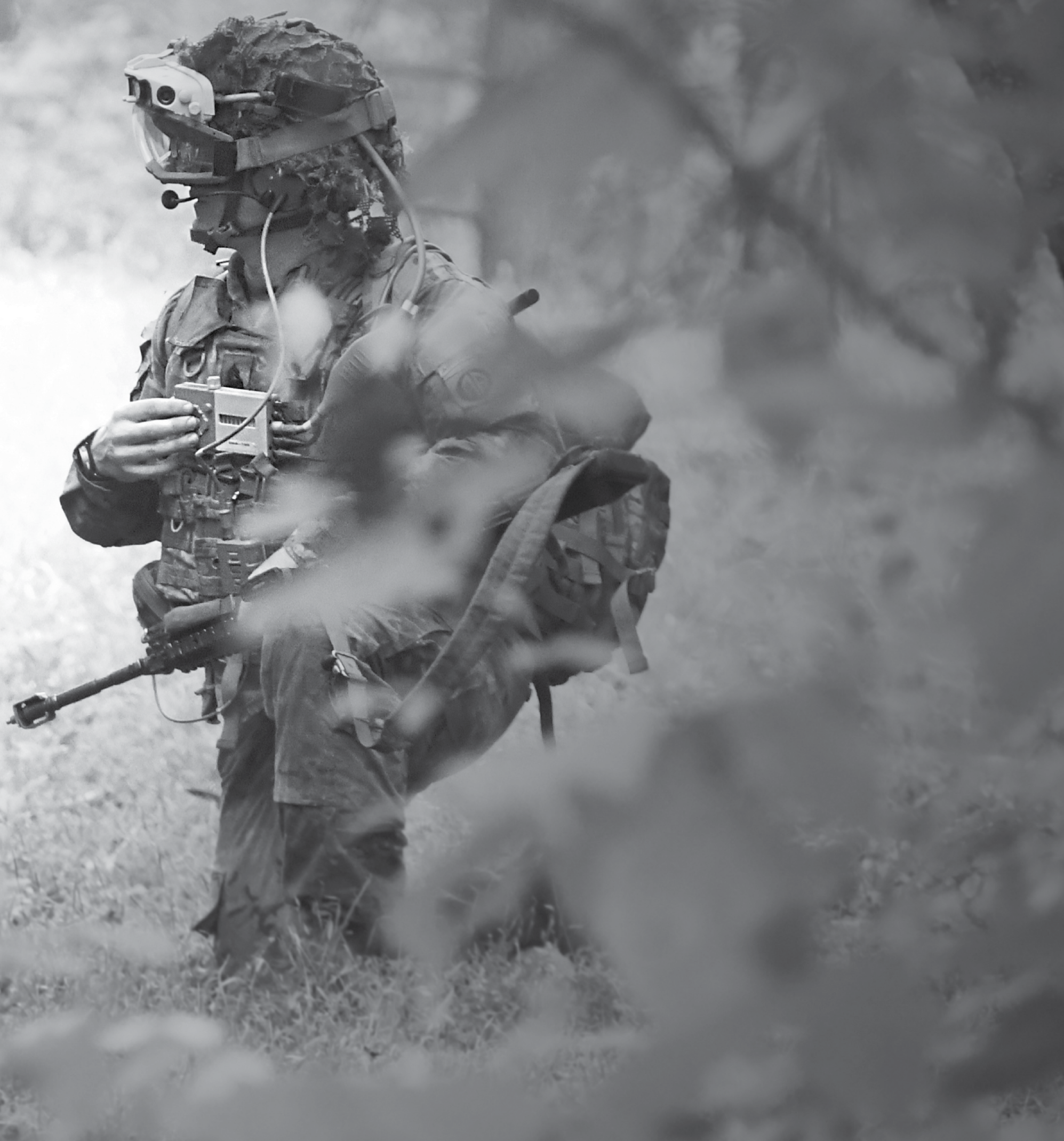




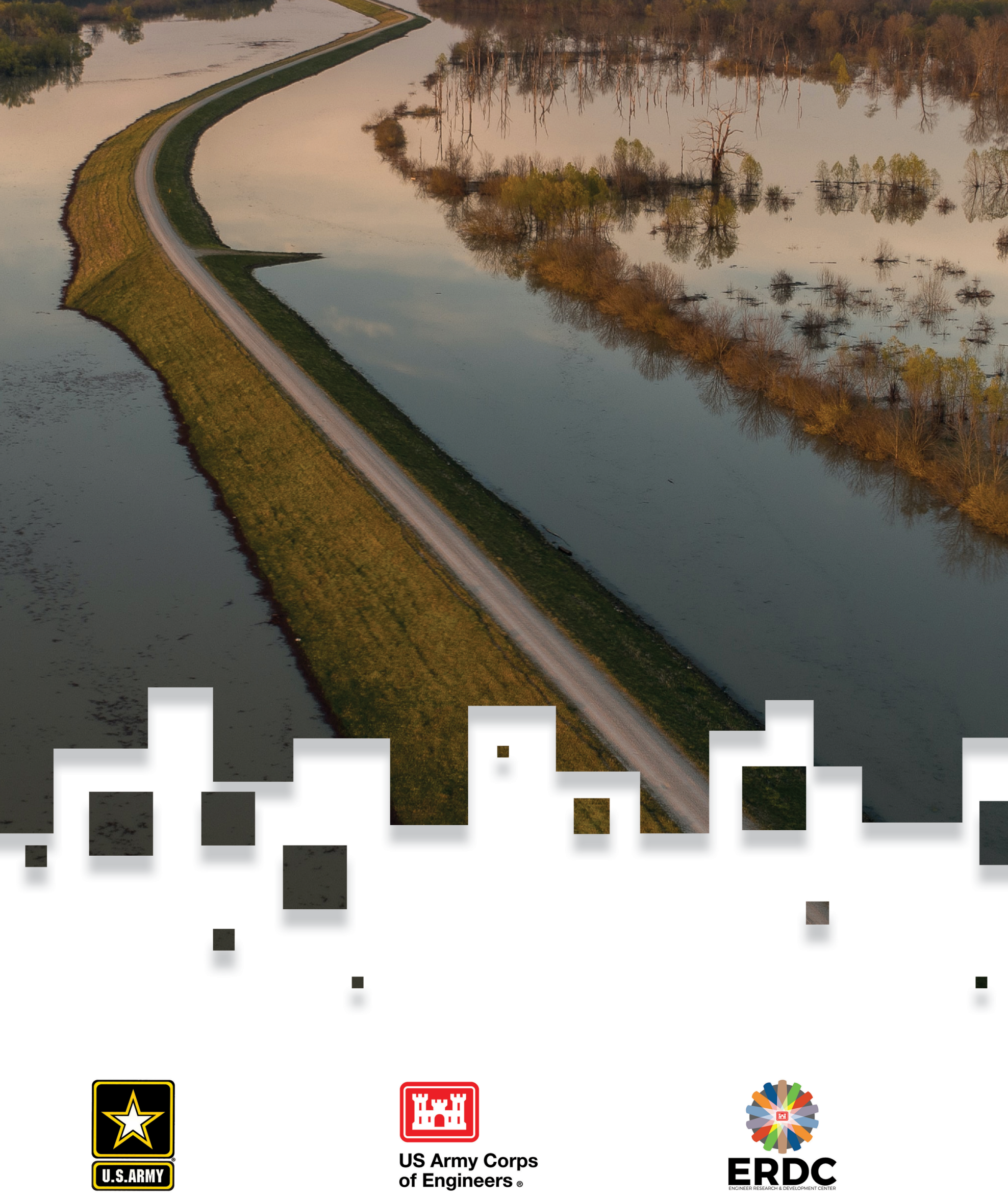

